\title{
How Indonesia Economics Works: Correlation Analysis of Macroeconomics in 2010 - 2019
}

\author{
Fahruddin Zain OLILINGO ${ }^{1}$, Aditya Halim Perdana Kusuma PUTRA ${ }^{2}$
}

Received: May 29, 2020 Revised: June 07, 2020 Accepted: July 09, 2020

\begin{abstract}
The purpose of this study is to provide benefits and ethically-rooted managerial implications based on theoretical underpinnings through an empirical study using correlation between wages, bank credit, government expenditure on economic growth, and employment via a case study in Indonesia. Besides that, managerial implications strive to provide benefits to the government regarding the importance of establishing effective and pro-development regulations to realize economic growth and employment through the efficient role of wages, bank credit, and government spending. This study uses secondary macroeconomic data from the period 2010-2019 with analysis using the correlation test with the Pearson correlation method. Out of eight hypotheses tested, two hypotheses do not have a significant correlation. The details of the statistical results obtained the following correlations: the correlation between bank credit and wages has a significant, but indirect (negative) correlation. However, the correlation between bank credit and economic growth has a direct and significant (positive) correlation. Government expenditure correlates positively with wages, but correlates negatively with bank credit. Wages are positively correlated with economic growth, but have no significant effect on employment. Finally, economic growth has a positive correlation with government expenditure, but does not have a significant correlation with employment.
\end{abstract}

Keywords : Bank Credit, Wages, Government Expenditure, Economics Growth, Employment

JEL Classification Code: H1, H5, J1

\section{Introduction}

The issue of wages is a fundamental element of economic principles in the world. In Indonesia alone, the government increases wages from year to year to improve people's living standards, evidenced by statistical data in the post-reform period, rising from IDR1,134,963 in 1997 to IDR2,455,716 in 2019. On the one hand, efforts to increase wages instantly eliminate the main problems that become the polemic of the national economy. The pros and cons of efforts to raise

${ }^{1}$ First Author and Corresponding Author. Associate Professor, Department of Economics Development Studies, Faculty of Economics, Universitas Negeri Gorontalo, Indonesia [Postal Address: Jend. Sudirman Street No. 6, Dulalowo Tim, GorontaloCity, Gorontalo, 96128, Indonesia] Email: fzo.fekonung@gmail.com ${ }^{2}$ Assistant Professor, Department of Management, Faculty of Economics and Business, Universitas Muslim Indonesia, Makassar, Indonesia. Email: adityatrojhan@gmail.com

(c) Copyright: The Author(s)

This is an Open Access article distributed under the terms of the Creative Commons Attribution Non-Commercial License (http://Creativecommons.org/licenses/by-nc/4.0/) which permits unrestricted noncommercial use, distribution, and reproduction in any medium, provided the original work is properly cited. salaries are still alive. Government efforts in maximizing the level of community welfare through wage increases are still considered small to meet the needs of people's lives. An increase in wages is undoubtedly a hope for workers. Where the delivery of wage increases will be in line with the fulfillment of a decent standard of living needs, an increase in public consumption is also considered. There is recognition of the achievements, skills, and abilities of workers in terms of competence and capability.

Increasing wages can also be considered as a simple solution to a problem. The impact of wage increases can harm the development of the business climate where one of the adverse effects caused after the determination of the minimum wage increase is the staff retrenchment (PHK) which can macro-impact on high unemployment and sluggish macroeconomic growth, including the growth of the economic sector, which will in turn have an impact on the consumption by the community itself (Böhm, 1978; Sasaki et al., 2013; Du \& Wang, 2019; Greiner et al., 2004; Lankisch et al., 2019; Okudaira et al., 2019). Several studies have made the variable wage a hot issue discussed among researchers who link wages and employment (e.g., Ariga \& 
Kambayashi, 2010; Baek \& Park, 2016; Dickson \& Fongoni, 2019; Holtemöller \& Pohle, 2019; Li et al., 2018; Perugini \& Pompei, 2016). From the economic theory and wage theory, there is causality between wages and labor absorption. Labor issues in Indonesia must receive serious attention from various parties, both government and private. Labor issues are the main problems that must be faced by the state and the people of Indonesia. So, it is suggested that the government should embrace the private sector to reduce and resolve labor problems jointly. The limited employment triggers some of the main issues of employment in Indonesia low quality of labor, high unemployment, wage factors, and social security factors that are considered inadequate.

The influence between wages and labor absorption can be realized as long as regulatory factors are seen to be flexible by the government; job security factors and aggregate demand for labor can take place in a positively environment (Ariga \& Kambayashi, 2010). But different opinions are expressed in research by Baek and Park (2016), which states that the increase in the minimum wage does not affect employment in the energy sector. Sasaki et al. (2013) states that a high wage rise will affect the economic balance and employment. Of course, the increase in wages is expected to be in line with the quality and quantity of production and labor factors, including the absorption of workers who are capable of both education and performance. Yamamoto et al. (2019) point out the information asymmetry factor towards employment in the Southeast by different levels of education. Yamamoto et al. (2019) show that education is a sub-factor that is very important in terms of employment other than wages.

In Indonesia, there is still a gender gap between male and female workers. The wage gap based on gender is assumed to be linked to the highest education level that has been completed in addition to socio-cultural issues that traditionally consider and view women as having a lower position than men. Apart from that, the wage gap between male and female workers is caused by differences in occupational and demographic characteristics, including work experience (www.tirto.id, 2018). Furthermore, the relationship between wages and economic growth is also clarified in several previous studies (e.g., Du \& Wang, 2019; Greiner et al., 2004; Lankisch et al., 2019; Okudaira et al., 2019). Causality is driven by macroeconomics where Grieben and Şener (2017) and Lingens (2007) revealed the bargaining power factor in international trade. Zagler (2005) says there is an impact on employment, which is correctly identified by the role of industry and innovation.

Furthermore, in the government's effort to increase economic growth in all investments, another way to look at is the effectiveness of state expenditure (government expenditure). Reflecting on the State Budget in Indonesia in 2018 , total state expenditure allocated a budget of 2,220.7 trillion rupiahs, where the most significant state expenditure category was budgeted for ministry and agency $(\mathrm{K} / \mathrm{L})$ expenditure of 847.4 trillion rupiahs, regional transfers and village funds amounting to 766.2 trillion and non-K / L expenditure of 607.1 trillion rupiah (www.kemenkeu.go.id, 2018). The purpose of the state expenditure is to implement social protection programs and sharpen social assistance, one of which is in education and health.

However, several aspects of the study state that government spending has a significant role in economic growth (Fizaine \& Court, 2016; Dahliah et al., 2020; Dinh, 2020; Luong et al., 2020), so is the causality between economic growth and employment, which must be bridged with government policy (Roşoiu, 2015), thereby increasing the level of community welfare (Sangha et al., 2019) and the level of acceptance of a country (Lukman et al., 2018). The correlation between bank credit growth and economic growth is in line with several research results including thereby increasing the level of community welfare (Bordo et al., 2016; Chi \& Li, 2017; Ketteni \& Kottaridi, 2019), which concluded that the intermediary role of banking institutions is very influential in a country's economic growth. When there is a decrease in the amount of credit extended due to caution from the bank, indirectly, there will be a slowdown in economic growth in the country concerned. There are different results regarding the relationship between bank credit and economic growth, Restrepo (2019) and Mandel and Seydl (2016) stated that the bank credit factor, which was bridged between economic and tax policies, did not affect economic growth.

The tricky problem with the issue of bank credit in Indonesia is the failure of a loan identified in the debtor identification procedure based on the principle of appropriateness. In addition to that, the problem of global economic instability is also a trigger, which also influences economic growth in Indonesia. Objectively, in several aspects, this current study differs from previous studies regarding the impact of minimum wages on the labor market in Indonesia, the effect of wages on economic growth, the impact of bank credit, and government spending both on economic growth and employment. Empirically, this study is expected to provide a picture, especially for the Indonesian government, of future macro and micro-economic strategies.

\section{Literature Review and Hypotheses Development}

Taylor et al. (2016) found that there was a significant positive effect between economic growth driven by an increase demand growth (see also Inchausti-Sintes, 2015), investment and investment implementation, distribution of goods, productivity, and a balance in the financial capital market and employment. It is in line with the results of studies (e.g., Auricchio et al., 2020; Bohlmann et al., 2019) 
from the standpoint of equilibrium theory, which adds to the variables of trade, household income, consumption and the level of exports and imports (Jin \& Rafferty, 2017). Then, the influence on employment will also be balanced by the existence of a remuneration system, as well as the development of environmental aspects (Ioan, 2014). The study is complemented by research (i.e., Kim et al., 2019; Soto, 2009; Sasaki, 2015), which states that a link between economic growth and employment can be realized when the factor of education, fiscal policy (Doménech et al., 2018), and the balance between job seekers based on gender can be realized ideally. This is also recognized by improving the quality of services and the effect of dollarization on state policy. However, different opinions are expressed by Ioan (2014) and Moutinho et al. (2015), who suggest that market demand, research and development from the government and universities have no significant effect on employment. Ioan stated in his study that investment is a counterweight to the short-term economic growth strategy and technological capacity advancement as a new strategy in terms of optimal employment.

Several researchers have found the influence and relationship between wages and labor absorption (e.g., Ariga \& Kambayashi, 2010; Baek \& Park, 2016; Dickson \& Fongoni, 2019; Holtemöller \& Pohle, 2019; Li et al., 2018; Perugini \& Pompei, 2016). The influence between wages and employment can be realized as long as regulation, job security, and aggregate demand for labor can take place positively. Whereas optimal wages and remuneration factors provide a real impact that bridges between wages and positive employment (Baek \& Park, 2016; Vazzana \& Bachmann, 1995; Clemens \& Wither, 2019; Caliendo et al., 2018; Bauducco \& Janiak, 2018), the factor of discrimination in terms of wages will harm employment (Borowczyk-Martins et al., 2017; Cheng et al., 2013; Perugini \& Pompei, 2016; Wang et al., 2019). Conversely, other studies (e.g., Lee \& Wolpin, 2010; Säve-Söderbergh, 2019; Schober \& WinterEbmer, 2011; Xu et al., 2015) found that differences between wages by gender did not affect employment.

Sasaki et al. (2013) states that a high rise will wage affect the economic balance and employment. Then from the aspect of wage theory and asymmetric approach says that the loss aversion factor of a worker and wages become contradictory. Dickson and Fongoni (2019) and $\mathrm{Su}$ et al. (2019) state that the loss aversion factor and asymmetric information bridge the relationship between wages and labor absorption, low loss aversion person, and the high level of asymmetry of personal details of a worker ignores the role of the minimum wage received. Yamamoto et al. (2019) states the information asymmetry factor towards employment in the Southeast by differences in educational levels. Yamamoto et al. (2019) make it clear that education is a sub-factor that is very important in terms of employment other than wages.
The link between wages and economic growth is shown in previous studies (e.g., Du \& Wang, 2019; Greiner et al., 2004), which state that there is a significant influence between low wages, the quality of labor skills and the mastery of technological factors. Lankisch et al. (2019) and Okudaira et al. (2019) stated that there was a significant influence, including low wages on the quality of the company, so that it had an impact on economic growth. In macroeconomics, Grieben and Şener (2017) and Lingens (2007) revealed the factor of bargaining power in international trade. Zagler (2005) also agrees, stating that low wages would have an impact on employment, correctly identifying industry and innovation. Palokangas (2009) suggests that employment can be realized as long as there is wage optimization and research and development support to produce innovation, especially for industry.

The relationship between government spending and employment has been echoed by several previous studies (e.g., Barrow, 2004; Polo et al., 2008), which justify the fact that there is a significant influence on the tourism sector by government spending on employment which is bridged by the level of education as well as government policy (Wu et al., 2010). Sangha et al. (2019) states that labor capability contributes to the high level of employment. From the military sector, the opposite facts are revealed by a few studies (e.g., Dunne \& Smith, 1990; Alptekin \& Levine, 2012; Manamperi, 2016; Yildirim \& Sezgin, 2003). They found an opposite fact where they considered that government spending on the military and defense had no effect on labor absorption from the military defense sector in developed countries, but has a significant impact on government spending on the military industry on economic growth for developing countries (Chen et al., 2014; Islam, 2015) including government spending in the forestry sector (Whiteman et al., 2015).

However, for the energy sector and energy policy, government spending in this sector has a significant role in terms of economic growth (Fizaine \& Court, 2016), as well as government policy (Roşoiu, 2015), public welfare (Sangha et al., 2019) and level of national income (Lukman et al., 2018).

In developing the conceptual framework in the third path analysis, which states the relationship between bank credit and employment, for example, Benmelech et al. (2019) states that there is a significant relationship between bank credit and employment from the viewpoint of economic theory by linking the relationship between confidence, taxation that is coercive, short-term compensation, and foreign debt. It is also in line with what has been disclosed (e.g., Cornille et al., 2019; García-Posada Gómez, 2019; Haltenhof et al., 2014; Popov \& Rocholl, 2018). However, different opinions were expressed by Degryse et al. (2019) and Han and 
Hare (2013). They revealed that bank credit did not have a significant impact on employment rates. Apart from that, several studies state the relationship between bank credit and economic growth is primarily influenced by several factors such as financial institutions and bank factors as well as business turnover and economic policy (Bordo et al., 2016; Chi \& Li, 2017; Hasanov \& Huseynov, 2013; Soedarmono et al., 2017; Ketteni \& Kottaridi, 2019), but a surprising point was made by Mandel and Seydl (2016), who argue that there is no significant relationship between bank credit and economic growth; other studies (i.e., Restrepo, 2019; Saksonova \& Koleda, 2017) suggest that industrial growth factors are a bridge between bank credit and economic growth. Based on the previous research matrix, and the relationship between the variables that have been presented, the following hypotheses are developed:

H1: Bank credit has a significant correlation with wages.

H2: Bank credit has a significant correlation with economic growth

H3: Government expenditure has a significant correlation with wages

H4: Government expenditure has a significant correlation with bank credit

H5: Wages have a significant correlation with economic growth

H6: Wages have a significant correlation with employment

H7: Economic growth has a significant correlation with government expenditure

H8: Economic growth has a significant correlation with employment

\section{Research Methods and Materials}

\subsection{Samples}

The data used in this research are descriptive quantitative data. This study's data sources are secondary data obtained from Indonesian macroeconomic data from 2010 to 2019, which includes data on wages, bank credit, government spending, economic growth, and employment.

\subsection{Measurement}

The measurement value equalization model requires several stages, such as variable investment and government expenditure, namely, data transformation using SPSS's Log10 compute variable. The next step is testing the normality using the asymptotic/Kolomogorv-Smirnov method to determine the correlation test, using the Pearson correlation method. After transforming the value variable, the trial is continued by testing the hypotheses through the correlation testing method with significance $(\mathrm{p}<0.05)$. The secondary data sample of the study is illustrated in Appendix 1.

Illustrations of recapitulation of the minimum wage variable data are calculated based on the average value of 34 provinces in Indonesia. Variable bank credit (i.e., average credit from the instruments of agriculture, hunting, fisheries, mining and quarrying, processing industry, gas and water electricity, construction, wholesale and retail trade, provision of accommodation and provision of food and beverages, transportation, warehousing and communication, financial intermediaries, real estate, rental business, and company services, government administration, defense and compulsory social security, educational facilities, health services, and social activities, community services, social culture, entertainment, and other individuals, individual services were serving households, international agencies and other international extra bodies, events which have unclear boundaries). The average variable of government expenditure is based on function (i.e., public services, defense, order and security, economy, environment, housing and public facilities, health, tourism and culture, religion, education, social protection). Complete economic growth variable and employment variable data are in Appendix 2.

\section{Results and Discussion}

\subsection{Results}

The statistical test referring to Section 3.2 is first to homogenize data values using the logmethod 10 described in Appendix 6. Then, in normality testing, the Asymptotic significance method with unstandardized residual values of XY (Res-1) obtained a value of $0.928>0.05$, which confirms that the data are normally distributed/parametric. The coefficient of determination (R-Square) predictors obtained a value of 0.691 and a value of $R=0.831$, so it can be concluded that all predictors are strongly related by $69.1 \%$. Cronbach's alpha predictor value produced a value of 0.735 , so the reliability of the predictor of the dependent variable is robust, which is equal to $73.5 \%$. Based on the results of hypothesis testing as well of the eight hypotheses developed in the previous section, two hypotheses do not support the variables that explain the relationship between wages on economic growth and economic growth on employment.

\subsection{Discussion}

We have demonstrated through the analysis of the correlation of each variable, that a reciprocal relationship posited in several hypotheses proves a significant influence both positively and negatively. On the other hand, there is 
Fahruddin Zain OLILINGO, Aditya Halim Perdana Kusuma PUTRA /

Journal of Asian Finance, Economics and Business Vol 7 No 8 (2020) 117-130

also a hypothesis that shows no significant effect at all. The factor of bank credit recorded during the years 2010 to 2019 on a micro-scale in banking in Indonesia is predominantly channeled to the gas and water electricity sector, while government spending is more dominant in the general public service sector, including; employee wages and others. The relationship that describes a significant negative correlation is assumed that the relationship between these variables requires an intermediate variable as an intervening relationship.

We highlight some of the results of studies that have a significant negative correlation, and we can conclude that significant negative means indirect correlation. Examples include the correlation between variables of bank credit on wages and the correlation between government expenditure on bank credit. This means that there is a significant result on the increase in wages driven by the rise in bank credit, so, there must be a connecting variable. We tried to simulate some variables as intervening variables in this study, for example, by modifying the model between bank credit as independent, economic growth as an intervening variable, and wages as the dependent variable with the regression model, but the results were not significant. An essential aspect in the discussion is how bank credit is directly linked to economic growth. This means that the community's outstanding bank credit assumes that it can increase economic growth and the velocity of money in the community. Economic activity that runs in the community will trigger significant state tax revenue, so that government expenditure will also increase primarily to raise wages so that rising wages will also trigger economic growth. In other words, economic stimulus in Indonesia does require debt in the form of bank credit to turn the wheels and the economic cycle, and finance several sectors for the needs of the people (see Figure 1). This statement is fundamental and rational. Given the economic growth in Indonesia over the last few years to $5 \%$ before the coronavirus pandemic, economic growth is also in line with the increase in Indonesia's foreign debt, which also continues to increase (See. www. databoks.katadata.co.id, 2020).

It is very rational to see how the role of government and private debt or credit banks have a significant impact on the economic wheels of the Indonesian economy because the most prominent government spending is the expenditure allocated to ministries/institutions or non-K/L and the financing of tactical funds again governmental needs. The dominant source of income comes from the tax sector and natural resource income. The natural resource income sector is not all owned by Indonesia, but still belongs to foreign companies (i.e., Vale, Chevron Pacific, Newmont, Freeport, PetroChina, Conoco Philips, BP, Niko Resources, etc). The positive side of bank credit can be a stimulus to increase economic growth. But of course, in a fair way, bank credit or macro debt will also have a negative impact, for example, it will put pressure on the tax sector that is increasingly large and massive to balance the debt position, and is feared to have an effect on fiscal, monetary, and state strategic policies. Wisely and ideally to overcome the adverse effects of the high debt burden in the form of credit banks in Indonesia, the government regulation policy is sought and maximized so that the debt function becomes effective as suggested in the study (Roşoiu, 2015; Sangha et al., 2019; Lukman et al., 2018).

Our study has also provided a comprehensive picture for academics and macroeconomic practitioners, specifically about the role of bank credit in increasing economic growth and its cycle, both at the macro and micro levels. This study also supports the assertion that there is a significant correlation and influence between government spending and bank credit on economic growth (e.g., Fizaine \& Court, 2016; Bordo et al., 2016; Chi \& Li, 2017; Ketteni \& Kottaridi, 2019; Cornille et al., 2019; García-Posada Gómez, 2019; Haltenhof et al., 2014; Popov \& Rocholl, 2018). It also provides differing opinions from Mandel and Seydl (2016), which suggested the role of government and private R\&D and the development of human capital form a bridging variable between government spending and economic growth; this study focuses more on the urgency of credit banks to increase economic growth and reflect increased government spending. Benmelech et al., (2019) revealed that there was a significant correlation between bank credit and employment. In contrast, in our study, the relationship can exist, but after passing through several stages, the implications are explained in Figure 1.

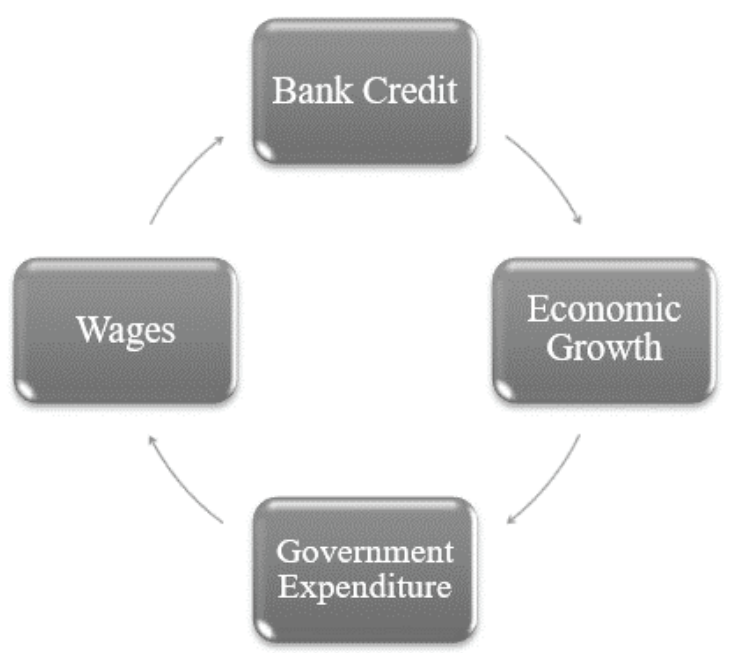

Figure 1: How the Indonesia Economics Works (Authors, 2020) 


\section{Conclusions}

This study has provided a broad picture on the vital role of bank credit in triggering effects on micro and macroeconomic growth to the stages where the contribution of bank credit can increase the value of wages. The existence of a negative correlation gives a significant signal that our assumption that the role of government regulations related to credit bank management professionally and ethically can be a good bridge in promoting economic growth. On the other hand, in addition to regulations regarding the optimal management and use of credit banks, it is also expected that our findings inform strategic economic policy. Further research could modify the model with variations in the intervening causality.

\section{References}

Alptekin, A., \& Levine, P. (2012). Military expenditure and economic growth: A meta-analysis. European Journal of Political Economy, 28(4), 636-650. https://doi.org/10.1016/j. ejpoleco.2012.07.002

Ariga, K., \& Kambayashi, R. (2010). Employment and wage adjustments at firms under distress in Japan: An analysis based upon a survey. Journal of the Japanese and International Economies, 24(2), 213-235. https://doi.org/10.1016/j. jjie.2009.12.005

Auricchio, M., Ciani, E., Dalmazzo, A., \& de Blasio, G. (2020). Redistributive public employment? A test for the South of Italy. Economics Letters, 186(January), 108787. https://doi. org/10.1016/j.econlet.2019.108787

Baek, J., \& Park, W. R. (2016). Minimum wage introduction and employment: Evidence from South Korea. Economics Letters, 139(February), 18-21. https://doi.org/10.1016/j. econlet.2015.12.014

Bauducco, S., \& Janiak, A. (2018). The macroeconomic consequences of raising the minimum wage: Capital accumulation, employment and the wage distribution. European Economic Review, 101(1151053), 57-76. https://doi. org/10.1016/j.euroecorev.2017.09.012

Benmelech, E., Frydman, C., \& Papanikolaou, D. (2019). Financial frictions and employment during the Great Depression. Journal of Financial Economics, 133(3), 541-563. https://doi. org/10.1016/j.jfineco.2019.02.005

Bohlmann, H. R., Horridge, J. M., Inglesi-Lotz, R., Roos, E. L., \& Stander, L. (2019). Regional employment and economic growth effects of South Africa's transition to low-carbon energy supply mix. Energy Policy, 128(July), 830-837. https:// doi.org/10.1016/j.enpol.2019.01.065

Böhm, V. (1978). Disequilibrium dynamics in a simple macroeconomic model. Journal of Economic Theory, 17(2), 179-199. $\quad$ https://doi.org/https://doi.org/10.1016/00220531(78)90070-4
Bordo, M. D., Duca, J. V., \& Koch, C. (2016). Economic policy uncertainty and the credit channel: Aggregate and bank level U.S. evidence over several decades. Journal of Financial Stability, 26(October), 90-106. https://doi.org/10.1016/j. jfs.2016.07.002

Borowczyk-Martins, D., Bradley, J., \& Tarasonis, L. (2017). Racial discrimination in the U.S. labor market: Employment and wage differentials by skill. Labour Economics, 49(August), 106-127. https://doi.org/10.1016/j.labeco.2017.09.007

Caliendo, M., Fedorets, A., Preuss, M., Schröder, C., \& Wittbrodt, L. (2018). The short-run employment effects of the German minimum wage reform. Labour Economics, 53(October), 4662. https://doi.org/10.1016/j.labeco.2018.07.002

Chen, P. F., Lee, C. C., \& Chiu, Y. Bin. (2014). The nexus between defense expenditure and economic growth: New global evidence. Economic Modelling, 36(January), 474-483. https:// doi.org/10.1016/j.econmod.2013.10.019

Cheng, Z., Guo, F., Hugo, G., \& Yuan, X. (2013). Employment and wage discrimination in the Chinese cities: A comparative study of migrants and locals. Habitat International, 39, 246-255. https://doi.org/10.1016/j.habitatint.2012.11.007

Chi, Q., \& Li, W. (2017). Economic policy uncertainty, credit risks and banks' lending decisions: Evidence from Chinese commercial banks. China Journal of Accounting Research, 10(1), 33-50. https://doi.org/10.1016/j.cjar.2016.12.001

Clemens, J., \& Wither, M. (2019). The minimum wage and the Great Recession: Evidence of effects on the employment and income trajectories of low-skilled workers. Journal of Public Economics, 170(February), 53-67. https://doi.org/10.1016/j. jpubeco.2019.01.004

Cornille, D., Rycx, F., \& Tojerow, I. (2019). Heterogeneous effects of credit constraints on SMEs' employment: Evidence from the European sovereign debt crisis. Journal of Financial Stability, 41(April), 1-13. https://doi.org/10.1016/j.jfs.2019.02.001

Dahliah, D., Kurniawan, A., \& Putra, A. H. P. K. (2020). Analysis and Strategy of Economic Development Policy for SMEs in Indonesia. Journal of Asian Finance, Economics and Business, 7(5), 103-110. https://doi.org/10.13106/jafeb.2020.vol7. no5.103

Dickson, A., \& Fongoni, M. (2019). Asymmetric referencedependent reciprocity, downward wage rigidity, and the employment contract. Journal of Economic Behavior and Organization, 163(July), 409-429. https://doi.org/10.1016/j. jebo.2019.05.006

Dinh, D. V.. (2020). Optimal Inflation Threshold and Economic Growth: Ordinal Regression Model Analysis. Journal of Asian Finance, Economics and Business, 7(5), 91-102. https://doi. org/10.13106/jafeb.2020.vol7.no5.091

Doménech, R., García, J. R., \& Ulloa, C. (2018). The effects of wage flexibility on activity and employment in Spain. Journal of Policy Modeling, 40(6), 1200-1220. https://doi.org/10.1016/j. jpolmod.2018.08.002 
Du, P., \& Wang, S. (2019). The effect of minimum wage on firm markup: Evidence from China. Economic Modelling, 86(March). 241-250. https://doi.org/10.1016/j.econmod.2019.10.012

Fizaine, F., \& Court, V. (2016). Energy expenditure, economic growth, and the minimum EROI of society. Energy Policy, 95, 172-186. https://doi.org/10.1016/j.enpol.2016.04.039

García-Posada Gómez, M. (2019). Credit constraints, firm investment and employment: Evidence from survey data. Journal of Banking and Finance, 99(February), 121-141. https://doi.org/10.1016/j.jbankfin.2018.11.016

Greiner, A., Rubart, J., \& Semmler, W. (2004). Economic growth, skill-biased technical change and wage inequality: A model and estimations for the US and Europe. Journal of Macroeconomics, 26(4), 597-621. https://doi.org/10.1016/j.jmacro.2003.05.001

Grieben, W. H., \& Şener, F. (2017). Wage bargaining, trade and growth. Research in Economics, 71(3), 564-587. https://doi. org/10.1016/j.rie.2017.07.001

Haltenhof, S., Jung Lee, S., \& Stebunovs, V. (2014). The credit crunch and fall in employment during the Great Recession. Journal of Economic Dynamics and Control, 43, 31-57. https:// doi.org/10.1016/j.jedc.2014.03.013

Han, L., \& Hare, D. (2013). The link between credit markets and self-employment choice among households in rural China. Journal of Asian Economics, 26(June), 52-64. https://doi. org/10.1016/j.asieco.2013.04.008

Hasanov, F., \& Huseynov, F. (2013). Bank credits and non-oil economic growth: Evidence from Azerbaijan. International Review of Economics and Finance, 27(June), 597-610. https:// doi.org/10.1016/j.iref.2013.02.005

Holtemöller, O., \& Pohle, F. (2019). Employment effects of introducing a minimum wage: The case of Germany. Economic Modelling. 89(July) https://doi.org/10.1016/j. econmod.2019.10.006

Inchausti-Sintes, F. (2015). Tourism: Economic growth, employment and Dutch Disease. Annals of Tourism Research, 54(September), 172-189. https://doi.org/10.1016/j. annals.2015.07.007

Ioan, D. (2014). Employment - Cause and Effect of the Economic Growth. Procedia Economics and Finance, 8(14), 268-274. https://doi.org/10.1016/s2212-5671(14)00090-2

Islam, M. N. (2015). Economic growth, repression, and state expenditure in non-democratic regimes. European Journal of Political Economy, 37(March), 68-85. https://doi.org/10.1016/j. ejpoleco.2014.10.006

Jin, J., \& Rafferty, P. (2017). Does congestion negatively affect income growth and employment growth? Empirical evidence from US metropolitan regions. Transport Policy, 55(December), 1-8. https://doi.org/10.1016/j.tranpol.2016.12.003

Ketteni, E., \& Kottaridi, C. (2019). Credit market deregulation and economic growth: Further insights using a marginal integration approach. Journal of Macroeconomics, 62(March), 103115. https://doi.org/10.1016/j.jmacro.2019.04.001
Kim, K., İlkkaracan, İ., \& Kaya, T. (2019). Public investment in care services in Turkey: Promoting employment \& gender inclusive growth. Journal of Policy Modeling, 41(6), 12101229. https://doi.org/10.1016/j.jpolmod.2019.05.002

Lankisch, C., Prettner, K., \& Prskawetz, A. (2019). How can robots affect wage inequality? Economic Modelling, 81(July), 161169. https://doi.org/10.1016/j.econmod.2018.12.015

Lee, D., \& Wolpin, K. I. (2010). Accounting for wage and employment changes in the US from 1968-2000: A dynamic model of labor market equilibrium. Journal of Econometrics, 156(1), 68-85. https://doi.org/10.1016/j.jeconom.2009.09.008

Li, Y., Holmes, G., Fraher, E. P., Mark, B. A., \& Jones, C. B. (2018). Primary Care Nurse Practitioner Wage Differences by Employment Setting. Nursing Outlook, 66(6), 528-538. https:// doi.org/10.1016/j.outlook.2018.06.009

Lingens, J. (2007). Unions, wage setting, and economic growth. Economic Modelling, 24(1), 167-188. https://doi.org/10.1016/j. econmod.2006.06.009

Lukman, A. F., Adebimpe, O., Onate, C. A., Ogundokun, R. O., Gbadamosi, B., \& O. Oluwayemi, M. (2018). Data on expenditure, revenue, and economic growth in Nigeria. Data in Brief, 20(October), 1704-1709. https://doi.org/10.1016/j. dib.2018.08.191

Luong, T. T. H., Nguyen, T. M., \& Nguyen, T. A. N. (2020). Rule of Law, Economic Growth and Shadow Economy in Transition Countries. Journal of Asian Finance, Economics and Business, 7(4), 145-154. https://doi.org/10.13106/jafeb.2020.vol7. no4.145

Manamperi, N. (2016). Does military expenditure hinder economic growth? Evidence from Greece and Turkey. Journal of Policy Modeling, 38(6), 1171-1193. https://doi.org/10.1016/j. jpolmod.2016.04.003

Mandel, B. R., \& Seydl, J. (2016). Credit conditions and economic growth: Recent evidence from US banks. Economics Letters, 147(October), 63-67. https://doi.org/10.1016/j. econlet.2016.08.017

Moutinho, R., Au-Yong-Oliveira, M., Coelho, A., \& Manso, J. P. (2015). Beyond the "Innovation's Black-Box": Translating R\&D outlays into employment and economic growth. SocioEconomic Planning Sciences, 50(June), 45-58. https://doi. org/10.1016/j.seps.2015.04.001

Okudaira, H., Takizawa, M., \& Yamanouchi, K. (2019). Minimum wage effects across heterogeneous markets. Labour Economics, 59(March), 110-122. https://doi.org/10.1016/j. labeco.2019.03.004

Palokangas, T. (2009). Economic growth with political lobbying and wage bargaining. IFAC Proceedings Volumes, 42(2). 58-63. https://doi.org/10.3182/20090506-3-sf-4003.00011

Perugini, C., \& Pompei, F. (2016). Employment protection and wage inequality within education groups in Europe. Journal of Policy Modeling, 38(5), 810-836. https://doi.org/10.1016/j. jpolmod.2016.03.015 
Popov, A., \& Rocholl, J. (2018). Do credit shocks affect labor demand? Evidence for employment and wages during the financial crisis. Journal of Financial Intermediation, 36(October), 16-27. https://doi.org/10.1016/j.jfi.2016.10.002

Restrepo, F. (2019). The effects of taxing bank transactions on bank credit and industrial growth: Evidence from Latin America. Journal of International Money and Finance, 93(May), 335355. https://doi.org/10.1016/j.jimonfin.2019.02.005

Roşoiu, I. (2015). The Impact of the Government Revenues and Expenditures on the Economic Growth. Procedia Economics and Finance, 32(15), 526-533. https://doi.org/10.1016/s22125671(15)01428-8

Saksonova, S., \& Koḷeda, O. (2017). Evaluating the Interrelationship between Actions of Latvian Commercial Banks and Latvian Economic Growth. Procedia Engineering, 178, 123-130. https://doi.org/10.1016/j.proeng.2017.01.075

Sangha, K. K., Gerritsen, R., \& Russell-Smith, J. (2019). Repurposing government expenditure for enhancing Indigenous well-being in Australia: A scenario analysis for a new paradigm. Economic Analysis and Policy, 63(September), 75-91. https:// doi.org/10.1016/j.eap.2019.04.011

Sasaki, H. (2015). Is Growth Declining in the Service Economy? Discussion Papers. Structural ChangeandEconomics Dynamics, 53(June), https://doi.org/10.1016/j.strueco.2020.01.004

Sasaki, H., Matsuyama, J., \& Sako, K. (2013). The macroeconomic effects of the wage gap between regular and non-regular employment and of minimum wages. Structural Change and Economic Dynamics, 26(September), 61-72. https://doi. org/10.1016/j.strueco.2013.06.001

Säve-Söderbergh, J. (2019). Gender gaps in salary negotiations: Salary requests and starting salaries in the field. Journal of Economic Behavior and Organization, 161(May), 35-51. https://doi.org/10.1016/j.jebo.2019.01.019

Soedarmono, W., Sitorus, D., \& Tarazi, A. (2017). Abnormal loan growth, credit information sharing and systemic risk in Asian banks. Research in International Business and Finance, 42(July), 1208-1218. https://doi.org/10.1016/j. ribaf.2017.07.058

Soto, R. (2009). Dollarization, economic growth, and employment. Economics Letters, 105(1), 42-45. https://doi.org/10.1016/j. econlet.2009.05.012
Taylor, L., Rezai, A., \& Foley, D. K. (2016). An integrated approach to climate change, income distribution, employment, and economic growth. Ecological Economics, 121(January), 196-205. https://doi.org/10.1016/j.ecolecon.2015.05.015

Vazzana, G., \& Bachmann, D. (1995). Cad Salary and Employment Study. Computer-Aided Design, 27(11), 795-803. https://doi. org/10.1016/0010-4485(95)00009-7

Wang, W., Phillips, P. C. B., \& Su, L. (2019). The heterogeneous effects of the minimum wage on employment across states. Economics Letters, 174, 179-185. https://doi.org/10.1016/j. econlet.2018.11.002

Whiteman, A., Wickramasinghe, A., \& Piña, L. (2015). Global trends in forest ownership, public income and expenditure on forestry and forestry employment. Forest Ecology and Management, 352(September), 99-108. https://doi. org/10.1016/j.foreco.2015.04.011

Wu, S. Y., Tang, J. H., \& Lin, E. S. (2010). The impact of government expenditure on economic growth: How sensitive to the level of development? Journal of Policy Modeling, 32(6), 804-817. https://doi.org/10.1016/j.jpolmod.2010.05.011

www.databoks.katadata.co.id. (2020). Indonesian Foreign Debt Reaches Rp 5,620 Trillion as of December 2019. Retrieved March 30, 2020 from: https://bit.ly/3dnoeyV

www.kemenkeu.go.id. (2018). APBN 2018 Information. Online Webpage. Retrieved March 30, 2020 from: https://bit. ly/36Bzxk8

www.tirto.id. (2018). The average income of women is still far below the salary of men. Retrieved March 30, 2020 from: https://bit.ly/2MaiDzC

$\mathrm{Xu}$, S., Huo, L., \& Shang, W. (2015). The impact of wage distributions on economics growth based on multi-agent simulation. Procedia Computer Science, 55, 809-817. https:// doi.org/10.1016/j.procs.2015.07.155

Yamamoto, Y., Matsumoto, K., Kawata, K., \& Kaneko, S. (2019). Gender-based differences in employment opportunities and wage distribution in Nepal. Journal of Asian Economics, 64(October), 101131. https://doi.org/10.1016/j.asieco.2019.07.004

Zagler, M. (2005). Wage pacts and economic growth. Journal of Economic Studies, 32(5), 420-434. https://doi. org/10.1108/01443580510622405 
Fahruddin Zain OLILINGO, Aditya Halim Perdana Kusuma PUTRA /

Appendix 1: Wages of 34 Province in Indonesia (In billion rupiah)

\begin{tabular}{|c|c|c|c|c|c|c|c|c|c|c|}
\hline \multirow{2}{*}{ Province } & \multicolumn{10}{|c|}{ Year } \\
\hline & 2010 & 2011 & 2012 & 2013 & 2014 & 2015 & 2016 & 2017 & 2018 & 2019 \\
\hline Aceh & 1.300 & 1.350 & 1.400 & 1.550 & 1.750 & 1.900 & 2.118 & 2.500 & 2.718 & 2.917 \\
\hline Sumatera Utara & 965 & 1.035 & 1.200 & 1.375 & 1.505 & 1.625 & 1.812 & 1.961 & 2.132 & 2.303 \\
\hline Sumatera Barat & 940 & 1.055 & 1.150 & 1.350 & 1.490 & 1.615 & 1.800 & 1.949 & 2.755 & 2.289 \\
\hline Riau & 1.016 & 1.120 & 1.238 & 1.400 & 1.700 & 1.878 & 2.095 & 2.538 & 1.888 & 2.662 \\
\hline Jambi & 900 & 1.028 & 1.142 & 1.300 & 1.502 & 1.710 & 1.906 & 2.358 & 2.074 & 2.424 \\
\hline Sumatera Selatan & 927 & 1.048 & 1.195 & 1.630 & 1.825 & 1.974 & 2.206 & 2.266 & 2.464 & 2.804 \\
\hline Bengkulu & 780 & 815 & 930 & 1.200 & 1.350 & 1.500 & 1.605 & 2.063 & 2.596 & 2.040 \\
\hline Lampung & 767 & 855 & 975 & 1.150 & 1.399 & 1.581 & 1.763 & 1.737 & 2.244 & 2.240 \\
\hline Bangka Belitung & 910 & 1.024 & 1.110 & 1.265 & 1.640 & 2.100 & 2.341 & 2.388 & 2.119 & 2.976 \\
\hline Kep. Riau & 925 & 975 & 1.015 & 1.365 & 1.665 & 1.954 & 2.178 & 1.908 & 2.563 & 2.769 \\
\hline Dki Jakarta & 1.118 & 1.290 & 1.529 & 2.200 & 2.441 & 2.700 & 3.100 & 1.931 & 1.544 & 3.941 \\
\hline Jawa Barat & 671 & 732 & 780 & 850 & 1.000 & 1.000 & 2.250 & 3.355 & 2.099 & 1.668 \\
\hline Jawa Tengah & 660 & 675 & 765 & 830 & 910 & 910 & - & 1.420 & 1.454 & 1.605 \\
\hline Di Yogyakarta & 746 & 808 & 892 & 947 & 988 & 988 & - & 1.367 & 1.486 & 1.571 \\
\hline Jawa Timur & 630 & 705 & 745 & 866 & 1.000 & 1.000 & - & 1.337 & 1.508 & 1.630 \\
\hline Banten & 955 & 1.000 & 1.042 & 1.170 & 1.325 & 1.600 & 1.784 & 1.388 & 3.648 & 2.268 \\
\hline Bali & 829 & 890 & 967 & 1.181 & 1.542 & 1.621 & 1.807 & 1.956 & 2.127 & 2.298 \\
\hline NTB & 891 & 950 & 1.000 & 1.100 & 1.210 & 1.330 & 1.483 & 1.631 & 2.543 & 2.012 \\
\hline NTT & 800 & 850 & 925 & 1.010 & 1.150 & 1.250 & 1.425 & 1.525 & 2.560 & 1.793 \\
\hline Kalimantan Barat & 741 & 802 & 900 & 1.060 & 1.380 & 1.560 & 1.739 & 1.883 & 2.454 & 2.211 \\
\hline Kalimantan Tengah & 986 & 1.134 & 1.327 & 1.553 & 1.724 & 1.896 & 2.057 & 2.258 & 2.047 & 2.663 \\
\hline Kalimantan Selatan & 1.024 & 1.126 & 1.225 & 1.337 & 1.620 & 1.870 & 2.085 & 2.227 & 2.421 & 2.652 \\
\hline Kalimantan Timur & 1.002 & 1.084 & 1.177 & 1.752 & 1.886 & 2.026 & 2.161 & 2.354 & 2.648 & 2.747 \\
\hline Kalimantan Utara & - & - & - & - & - & 2.026 & 2.175 & 2.359 & 2.193 & 2.765 \\
\hline Sulawesi Utara & 1.000 & 1.050 & 1.250 & 1.550 & 1.900 & 2.150 & 2.400 & 2.030 & 2.824 & 3.051 \\
\hline Sulawesi Tengah & 777 & 827 & 885 & 995 & 1.250 & 1.500 & 1.670 & 2.598 & 1.965 & 2.123 \\
\hline Sulawesi Selatan & 1.000 & 1.100 & 1.200 & 1.440 & 1.800 & 2.000 & 2.250 & 1.808 & 2.177 & 2.860 \\
\hline Sulawesi Tenggara & 860 & 930 & 1.032 & 1.125 & 1.400 & 1.652 & 1.850 & 2.002 & 2.222 & 2.352 \\
\hline Gorontalo & 710 & 762 & 837 & 1.175 & 1.325 & 1.600 & 1.875 & 2.435 & 2.207 & 2.400 \\
\hline Sulawesi Barat & 944 & 1.006 & 1.127 & 1.165 & 1.400 & 1.655 & 1.864 & 2.017 & - & 2.369 \\
\hline Maluku & 840 & 900 & 975 & 1.275 & 1.415 & 1.650 & 1.775 & 1.925 & 1.825 & 2.400 \\
\hline Maluku Utara & 847 & 889 & 961 & 1.200 & 1.440 & 1.577 & 1.681 & 1.975 & 1.660 & 2.508 \\
\hline Papua Barat & 1.210 & 1.410 & 1.450 & 1.720 & 1.870 & 2.015 & 2.237 & 2.663 & 2.667 & 2.934 \\
\hline Papua & 1.316 & 1.403 & 1.585 & 1.710 & 2.040 & 2.193 & 2.435 & 2.421 & 2.895 & 3.240 \\
\hline
\end{tabular}


Appendix 2: Data on Bank Credit in Indonesia Conducted by Function (in billions of rupiah)

\begin{tabular}{|c|c|c|c|c|c|c|c|c|c|}
\hline \multirow{2}{*}{ Function } & \multicolumn{9}{|c|}{ Year } \\
\hline & 2011 & 2012 & 2013 & 2014 & 2015 & 2016 & 2017 & 2018 & 2019 \\
\hline Agriculture, Hunting & 1.584 & 3.106 & 2.943 & 2.922 & 2.812 & 2.651 & 3.759 & 4.191 & 6.874 \\
\hline Fishery & 133 & 106 & 103 & 101 & 102 & 100 & 99 & 112 & 109 \\
\hline Mining and excavation & 321 & 2 & 1.265 & 1 & 159 & 2 & 27 & 3 & 3 \\
\hline Processing industry & 2.868 & 3.756 & 4.356 & 3.276 & 3.373 & 248 & 249 & 852 & 41 \\
\hline Gas and water electricity & 9.999 & 8.127 & 8.581 & 7.093 & 7.048 & 4 & 4 & 4 & 108 \\
\hline Construction & 766 & 804 & 1.002 & 1.037 & 1.133 & 31 & 36 & 16 & 15 \\
\hline Wholesale and retail & 529 & 481 & 804 & 844 & 715 & 584 & 597 & 579 & 511 \\
\hline $\begin{array}{l}\text { Provision of accommodation } \\
\text { and Provision of food and } \\
\text { drink }\end{array}$ & 3.689 & 40 & 16 & 91 & 39 & 39 & 35 & 36 & 46 \\
\hline $\begin{array}{l}\text { Transportation, warehousing, } \\
\text { and communication }\end{array}$ & 2.822 & 1.916 & 2.002 & 1.741 & 1.819 & 34 & 32 & 40 & 340 \\
\hline Financial intermediaries & 20 & 408 & 346 & 355 & 453 & 480 & 601 & 540 & 469 \\
\hline $\begin{array}{l}\text { Real estate, rental business, } \\
\text { and company services }\end{array}$ & 205 & 175 & 171 & 600 & 222 & 176 & 160 & 160 & 157 \\
\hline $\begin{array}{l}\text { Administration of } \\
\text { government, } \\
\text { defense, and social security }\end{array}$ & 198 & 200 & 197 & 199 & 178 & 40 & 40 & 40 & 40 \\
\hline Educational services & 0 & 30 & 30 & 30 & 30 & 30 & 30 & 30 & 38 \\
\hline $\begin{array}{l}\text { Health services and } \\
\text { social activities }\end{array}$ & 70 & 80 & 73 & 90 & 96 & 93 & 93 & 96 & 93 \\
\hline $\begin{array}{l}\text { Community services, } \\
\text { social culture, } \\
\text { entertainment }\end{array}$ & 578 & 539 & 550 & 529 & 535 & 516 & 526 & 525 & 523 \\
\hline $\begin{array}{l}\text { Individual services } \\
\text { serving households }\end{array}$ & 25 & 21 & 189 & 13 & 13 & 12 & 12 & 12 & 11 \\
\hline $\begin{array}{l}\text { International Bodies and } \\
\text { other international Extra } \\
\text { Bodies }\end{array}$ & 82 & 85 & - & 80 & 79 & 77 & 74 & 83 & 82 \\
\hline $\begin{array}{l}\text { Activities that have no clear } \\
\text { boundaries }\end{array}$ & 5.536 & 4.702 & 4.747 & 4.300 & 4.253 & 4.326 & 4.048 & 4.754 & 4.463 \\
\hline
\end{tabular}


Fahruddin Zain OLILINGO, Aditya Halim Perdana Kusuma PUTRA /

Appendix 3: Government Expenditures Based on Function (In Billion rupiah)

\begin{tabular}{|l|c|c|c|c|c|c|c|c|c|c|}
\hline \multicolumn{1}{|c|}{ Function } & $\mathbf{2 0 1 0}$ & $\mathbf{2 0 1 1}$ & $\mathbf{2 0 1 2}$ & $\mathbf{2 0 1 3}$ & $\mathbf{2 0 1 4}$ & $\mathbf{2 0 1 5}$ & $\mathbf{2 0 1 6}$ & $\mathbf{2 0 1 7}$ & $\mathbf{2 0 1 8}$ & $\mathbf{2 0 1 9}$ \\
\hline Public service & 495.320 & 517.167 & 647.998 & 705.724 & 797.763 & 624.497 & 275.123 & 307.147 & 375.196 & 440.928 \\
\hline Defense & 20.968 & 47.419 & 61.226 & 87.510 & 86.113 & 105.907 & 98.248 & 117.506 & 106.832 & 107.426 \\
\hline Order and security & 14.926 & 22.067 & 29.096 & 36.120 & 34.856 & 52.941 & 113.349 & 135.748 & 143.305 & 140.660 \\
\hline The economy & 57.359 & 101.414 & 105.574 & 108.082 & 97.140 & 177.105 & 288.344 & 307.787 & 382.420 & 384.134 \\
\hline Living environment & 7.889 & 11.070 & 8.814 & 10.590 & 9.326 & 9.874 & 8.941 & 10.613 & 13.709 & 14.031 \\
\hline $\begin{array}{l}\text { Housing and } \\
\text { public facilities }\end{array}$ & 20.907 & 23.425 & 26.440 & 33.790 & 26.244 & 16.981 & 27.816 & 27.277 & 32.198 & 21.596 \\
\hline Health & 18.002 & 13.649 & 15.181 & 17.577 & 10.893 & 23.225 & 59.639 & 57.225 & 61.869 & 59.675 \\
\hline $\begin{array}{l}\text { Tourism and } \\
\text { culture }\end{array}$ & 1.416 & 2.901 & 2.516 & 1.818 & 1.469 & 3.166 & 4.379 & 5.770 & 10.700 & 3.891 \\
\hline Religion & 913 & 1.397 & 3.419 & 3.872 & 4.001 & 5.097 & 8.463 & 8.870 & 9.379 & 10.027 \\
\hline Education & 84.086 & 91.483 & 105.207 & 114.969 & 122.697 & 143.638 & 131.974 & 138.507 & 145.941 & 149.877 \\
\hline Social protection & 3.457 & 4.586 & 5.081 & 17.107 & 13.070 & 20.867 & 137.737 & 148.905 & 173.771 & 194.903 \\
\hline
\end{tabular}


Appendix 4: Economics Growth (In Percentage)

\begin{tabular}{|c|c|c|c|c|c|c|c|c|c|c|}
\hline Province & 2009 & 2010 & 2011 & 2012 & 2013 & 2014 & 2015 & 2016 & 2017 & 2018 \\
\hline Aceh & $-5,51$ & 2,74 & 3,28 & 3,85 & 2,61 & 1,55 & $-0,73$ & 3,29 & 4,18 & 4,61 \\
\hline Sumatera Utara & 5,07 & 6,42 & 6,66 & 6,45 & 6,07 & 5,23 & 5,1 & 5,18 & 5,12 & 5,18 \\
\hline Sumatera Barat & 4,28 & 5,94 & 6,34 & 6,31 & 6,08 & 5,88 & 5,53 & 5,27 & 5,29 & 5,14 \\
\hline Riau & 2,97 & 4,21 & 5,57 & 3,76 & 2,48 & 2,71 & 0,22 & 2,18 & 2,68 & 2,34 \\
\hline Jambi & 6,39 & 7,35 & 7,86 & 7,03 & 6,84 & 7,36 & 4,21 & 4,37 & 4,64 & 4,71 \\
\hline Sumatera Selatan & 4,11 & 5,63 & 6,36 & 6,83 & 5,31 & 4,79 & 4,42 & 5,04 & 5,51 & 6,04 \\
\hline Bengkulu & 5,62 & 6,1 & 6,85 & 6,83 & 6,07 & 5,48 & 5,13 & 5,28 & 4,98 & 4,99 \\
\hline Lampung & 5,26 & 5,88 & 6,56 & 6,44 & 5,77 & 5,08 & 5,13 & 5,14 & 5,16 & 5,25 \\
\hline $\begin{array}{l}\text { Kep. Bangka } \\
\text { Belitung }\end{array}$ & 3,74 & 5,99 & 6,9 & 5,5 & 5,2 & 4,67 & 4,08 & 4,1 & 4,47 & 4,45 \\
\hline Kep. Riau & 3,52 & 7,19 & 6,96 & 7,63 & 7,21 & 6,6 & 6,02 & 4,98 & 2 & 4,56 \\
\hline Dki Jakarta & 5,02 & 6,5 & 6,73 & 6,53 & 6,07 & 5,91 & 5,91 & 5,87 & 6,2 & 6,17 \\
\hline Jawa Barat & 4,19 & 6,2 & 6,5 & 6,5 & 6,33 & 5,09 & 5,05 & 5,66 & 5,35 & 5,64 \\
\hline Jawa Tengah & 5,14 & 5,84 & 5,3 & 5,34 & 5,11 & 5,27 & 5,47 & 5,25 & 5,26 & 5,32 \\
\hline DI Yogyakarta & 4,43 & 4,88 & 5,21 & 5,37 & 5,47 & 5,17 & 4,95 & 5,05 & 5,26 & 6,2 \\
\hline Jawa Timur & 5,01 & 6,68 & 6,44 & 6,64 & 6,08 & 5,86 & 5,44 & 5,57 & 5,46 & 5,5 \\
\hline Banten & 4,71 & 6,11 & 7,03 & 6,83 & 6,67 & 5,51 & 5,45 & 5,28 & 5,73 & 5,81 \\
\hline Bali & 5,33 & 5,83 & 6,66 & 6,96 & 6,69 & 6,73 & 6,03 & 6,33 & 5,57 & 6,35 \\
\hline $\begin{array}{l}\text { Nusa Tenggara } \\
\text { Barat }\end{array}$ & 12,14 & 6,35 & $-3,91$ & $-1,54$ & 5,16 & 5,17 & 21,76 & 5,81 & 0,12 & $-4,56$ \\
\hline $\begin{array}{l}\text { Nusa Tenggara } \\
\text { Timur }\end{array}$ & 4,29 & 5,25 & 5,67 & 5,46 & 5,41 & 5,05 & 4,92 & 5,12 & 5,11 & 5,13 \\
\hline Kalimantan Barat & 4,8 & 5,47 & 5,5 & 5,91 & 6,05 & 5,03 & 4,88 & 5,2 & 5,17 & 5,06 \\
\hline Kalimantan Tengah & 5,57 & 6,5 & 7,01 & 6,87 & 7,37 & 6,21 & 7,01 & 6,35 & 6,72 & 5,64 \\
\hline Kalimantan Selatan & 5,29 & 5,59 & 6,97 & 5,97 & 5,33 & 4,84 & 3,82 & 4,4 & 5,28 & 5,13 \\
\hline Kalimantan Timur & 2,28 & 5,1 & 6,47 & 5,48 & 2,76 & 1,71 & $-1,2$ & $-0,38$ & 3,13 & 2,67 \\
\hline Kalimantan Utara & - & - & - & - & - & 8,18 & 3,4 & 3,55 & 6,79 & 6,04 \\
\hline Sulawesi Utara & 7,85 & 7,16 & 6,17 & 6,86 & 6,38 & 6,31 & 6,12 & 6,16 & 6,31 & 6,01 \\
\hline Sulawesi Tengah & 7,71 & 8,74 & 9,82 & 9,53 & 9,59 & 5,07 & 15,5 & 9,94 & 7,1 & 6,3 \\
\hline Sulawesi Selatan & 6,23 & 8,19 & 8,13 & 8,87 & 7,62 & 7,54 & 7,19 & 7,42 & 7,21 & 7,07 \\
\hline Sulawesi Tenggara & 7,57 & 8,22 & 10,63 & 11,65 & 7,5 & 6,26 & 6,88 & 6,51 & 6,76 & 6,42 \\
\hline Gorontalo & 7,54 & 7,63 & 7,71 & 7,91 & 7,67 & 7,27 & 6,22 & 6,52 & 6,73 & 6,51 \\
\hline Sulawesi Barat & 6,03 & 11,89 & 10,73 & 9,25 & 6,93 & 8,86 & 7,31 & 6,01 & 6,62 & 6,23 \\
\hline Maluku & 5,44 & 6,47 & 6,34 & 7,16 & 5,24 & 6,64 & 5,48 & 5,73 & 5,82 & 5,94 \\
\hline Maluku Utara & 6,07 & 7,95 & 6,8 & 6,98 & 6,36 & 5,49 & 6,1 & 5,77 & 7,67 & 7,92 \\
\hline Papua Barat & 13,87 & 28,47 & 3,64 & 3,63 & 7,36 & 5,38 & 4,15 & 4,52 & 4,01 & 6,24 \\
\hline Papua & 22,22 & $-3,19$ & $-4,28$ & 1,72 & 8,55 & 3,65 & 7,35 & 9,14 & 4,64 & 7,33 \\
\hline
\end{tabular}


Fahruddin Zain OLILINGO, Aditya Halim Perdana Kusuma PUTRA /

Appendix 5: Employment (In Percentage)

\begin{tabular}{|c|c|c|c|c|c|c|c|c|c|}
\hline \multirow{2}{*}{ Province } & \multicolumn{9}{|c|}{ Tahun } \\
\hline & 2010 & 2011 & 2012 & 2013 & 2014 & 2015 & 2016 & 2017 & 2018 \\
\hline Aceh & 63,17 & 62,53 & 61,72 & 62,24 & 63,06 & 63,44 & 64,26 & 63,74 & 64,24 \\
\hline Sumatera Utara & 69,51 & 67,62 & 69,27 & 70,62 & 67,07 & 67,28 & 65,99 & 68,88 & 71,82 \\
\hline Sumatera Barat & 66,36 & 65,33 & 64,42 & 62,92 & 65,19 & 64,56 & 67,08 & 66,29 & 67,27 \\
\hline Riau & 63,66 & 63,21 & 62,52 & 63,44 & 63,31 & 63,22 & 66,25 & 64,00 & 65,23 \\
\hline Jambi & 65,78 & 65,48 & 64,92 & 62,68 & 65,59 & 66,14 & 67,54 & 67,52 & 68,46 \\
\hline Sumatera Selatan & 70,23 & 68,30 & 69,61 & 66,75 & 68,85 & 68,53 & 71,59 & 69,50 & 68,69 \\
\hline Bengkulu & 71,86 & 70,22 & 70,14 & 67,59 & 68,29 & 70,67 & 72,69 & 69,30 & 70,06 \\
\hline Lampung & 67,95 & 65,27 & 66,30 & 64,84 & 66,99 & 65,60 & 69,61 & 67,83 & 69,67 \\
\hline Bangka-Belitung & 66,53 & 64,19 & 65,58 & 65,38 & 65,45 & 66,71 & 68,93 & 66,72 & 67,79 \\
\hline Kepulauan Riau & 68,85 & 65,71 & 66,92 & 65,92 & 65,95 & 65,07 & 65,93 & 66,41 & 64,72 \\
\hline DKI Jakarta & 67,83 & 69,30 & 71,47 & 67,79 & 66,61 & 66,39 & 66,91 & 61,97 & 63,95 \\
\hline Jawa Barat & 62,38 & 61,34 & 63,64 & 62,82 & 62,77 & 60,34 & 60,65 & 63,34 & 62,92 \\
\hline Jawa Tengah & 70,60 & 70,15 & 71,26 & 70,43 & 69,68 & 67,86 & 67,15 & 69,11 & 68,56 \\
\hline DI Yogyakarta & 69,76 & 70,15 & 71,37 & 69,29 & 71,05 & 68,38 & 71,96 & 71,52 & 73,37 \\
\hline Jawa Timur & 69,08 & 68,06 & 69,60 & 69,78 & 68,12 & 67,84 & 66,14 & 68,78 & 69,37 \\
\hline Banten & 65,34 & 65,61 & 65,17 & 63,55 & 63,84 & 62,24 & 63,66 & 62,32 & 63,49 \\
\hline Bali & 77,38 & 75,19 & 76,58 & 74,93 & 74,91 & 75,51 & 77,24 & 75,24 & 76,78 \\
\hline Nusa Tenggara Barat & 66,63 & 65,71 & 65,93 & 65,42 & 66,63 & 66,54 & 71,57 & 68,49 & 65,91 \\
\hline Nusa Tenggara Timur & 72,77 & 68,58 & 69,98 & 68,15 & 68,91 & 69,25 & 69,18 & 69,09 & 70,17 \\
\hline Kalimantan Barat & 73,17 & 72,41 & 71,40 & 69,53 & 69,93 & 69,68 & 69,32 & 68,63 & 68,65 \\
\hline Kalimantan Tengah & 69,86 & 70,14 & 69,88 & 68,50 & 68,56 & 71,11 & 71,30 & 67,74 & 70,03 \\
\hline Kalimantan Selatan & 71,26 & 71,94 & 71,95 & 69,31 & 69,46 & 69,73 & 71,57 & 70,06 & 70,27 \\
\hline Kalimantan Timur & 66,41 & 66,56 & 66,37 & 63,50 & 64,10 & 62,39 & 67,79 & 63,75 & 64,99 \\
\hline Kalimantan Utara & - & - & - & - & - & 63,45 & 62,40 & 68,24 & 67,81 \\
\hline Sulawesi Utara & 63,31 & 62,66 & 61,54 & 59,41 & 59,99 & 61,28 & 65,11 & 60,85 & 63,01 \\
\hline Sulawesi Tengah & 69,22 & 68,65 & 65,92 & 65,56 & 66,76 & 67,51 & 72,28 & 67,14 & 69,52 \\
\hline Sulawesi Selatan & 64,14 & 63,43 & 62,71 & 60,32 & 62,04 & 60,94 & 62,92 & 60,98 & 63,02 \\
\hline Sulawesi Tenggara & 71,86 & 66,73 & 67,30 & 65,91 & 66,87 & 68,35 & 73,47 & 68,70 & 69,78 \\
\hline Gorontalo & 64,42 & 64,06 & 62,57 & 61,46 & 62,84 & 63,65 & 67,89 & 64,78 & 67,34 \\
\hline Sulawesi Barat & 71,46 & 69,87 & 71,71 & 66,83 & 71,06 & 70,27 & 71,90 & 66,96 & 68,46 \\
\hline Maluku & 66,48 & 67,21 & 62,94 & 61,93 & 60,92 & 64,47 & 64,51 & 60,18 & 62,90 \\
\hline Maluku Utara & 65,11 & 64,57 & 66,05 & 64,35 & 63,88 & 66,43 & 66,19 & 63,65 & 65,21 \\
\hline Papua Barat & 69,29 & 66,87 & 67,20 & 66,69 & 68,30 & 68,68 & 70,05 & 67,47 & 67,88 \\
\hline Papua & 80,99 & 77,75 & 78,18 & 77,70 & 78,67 & 79,57 & 76,70 & 76,94 & 79,11 \\
\hline Indonesia & 66,55 & 65,44 & 65,65 & 64,28 & 64,87 & 66,85 & 68,46 & 66,94 & 67,95 \\
\hline
\end{tabular}


Appendix 6: Statistical Analysis

\begin{tabular}{|c|c|c|c|c|c|}
\hline \multicolumn{6}{|c|}{ Transformation Log10 } \\
\hline Wages & Bank Credit & $\begin{array}{l}\text { Government } \\
\text { Expenditure }\end{array}$ & $\begin{array}{l}\text { Economics } \\
\text { Growth }\end{array}$ & Employment & $\begin{array}{l}\text { Unstandardized } \\
\text { Residual }\end{array}$ \\
\hline 5.96 & 3.21 & 4.82 & 5.88 & 65.69 & 0.0829 \\
\hline 6.0 & 3.21 & 4.88 & 6.83 & 66.55 & 0.90478 \\
\hline 6.04 & 3.14 & 4.96 & 6.08 & 65.44 & -0.0990 \\
\hline 6.11 & 3.21 & 5.01 & 6.26 & 65.65 & 0.4530 \\
\hline 6.18 & 3.11 & 5.04 & 6.1 & 64.28 & -1.4242 \\
\hline 6.23 & 3.11 & 5.03 & 5.52 & 64.87 & -0.8967 \\
\hline 6.3 & 2.72 & 5.02 & 5.71 & 66.85 & -1.1136 \\
\hline 6.32 & 2.76 & 5.06 & 5.34 & 68.46 & 0.9139 \\
\hline 6.36 & 2.83 & 5.12 & 5.24 & 66.94 & -0.0638 \\
\hline 6.39 & 2.89 & 5.14 & 5.27 & 67.95 & 1.2427 \\
\hline \multicolumn{6}{|c|}{ Normality Test } \\
\hline & & & \multicolumn{3}{|c|}{ Unstandardized Residual } \\
\hline $\mathrm{N}$ & & & \multicolumn{3}{|c|}{10} \\
\hline Normal Par & \multicolumn{2}{|c|}{$\begin{array}{l}\text { Mean } \\
\text { Standard Deviation }\end{array}$} & \multicolumn{3}{|c|}{$\begin{array}{l}.0000000 \\
.00733673\end{array}$} \\
\hline Most Extrer & Differences & & & & \\
\hline Absolute & $\begin{array}{l}\text { Positive } \\
\text { Negative }\end{array}$ & & & & \\
\hline Kolmogoro & nirnov Z & & & & \\
\hline Asymp. Sig & -tailed) & & & & \\
\hline & & $R=0.831$ & Square $=0.6$ & Ipha $=$ & \\
\hline & & Hypoth & sis Test with $\mathrm{F}$ & tion $\mathrm{Te}$ & \\
\hline & Model & & $\begin{array}{l}\text { Pearson } \\
\text { Correlation }\end{array}$ & & Result \\
\hline Bank Credi & Wages & & -0.854 & 0.05 & Negative Significant \\
\hline Bank Credi & Economics Gro & wth & 0.726 & $=0.05$ & Positive Significant \\
\hline Governmen & xpenditure $\rightarrow$ W & lages & 0.928 & $<0.01$ & Positive Significant \\
\hline Governmen & xpenditure $\rightarrow B$ & ank Credit & -0.661 & $=0.01$ & Negative Significant \\
\hline Wages $\rightarrow \mathrm{E}$ & nomics Growth & & -0.811 & $=0.05$ & Positive Significant \\
\hline Wages $\rightarrow \mathrm{E}$ & loyment & & 0.548 & 0.05 & Insignificant \\
\hline $\begin{array}{l}\text { Economics } \\
\text { Expenditure }\end{array}$ & wth $\rightarrow$ Govern & ment & -0.691 & $=0.05$ & Positive Significant \\
\hline Economics & wth $\rightarrow$ Employ & ment & -0.462 & 0.05 & Insignificant \\
\hline
\end{tabular}

